\title{
Canadian Role in the Korea War, 1950-53
}

by

\author{
Suffian Mansor
}

\section{INTRODUCTION}

At 4:00 a.m. on the Saturday morning of June 25,1950 , the North Korean army crossed the $38^{\text {th }}$ parallel into South Korea. This was the beginning of the Korean War; it also brought about a swift response from both the United States and the United Nations. Harry Truman, the United States president, had authorised General Douglas MacArthur to evacuate all American subjects from South Korea. He also ordered the Americans Navy to be despatched immediately to Korea. On the same day of the attack, the United Nations Security Council had issued a resolution which denounced North Korea's attack, and called for an immediate cessation of hostilities and the withdrawal of the North Korean army. This resolution was passed by a vote of 9 to 0 , with Yugoslavia abstaining. A second resolution was passed on June 27, 1950, which called upon members of the United Nations to provide assistance to the Republic of Korea (South Korea) in resisting aggression. This time the vote was supported by seven members. India and Egypt abstained. Only Yugoslavia opposed the resolution. ${ }^{1}$ On both occasions, the Soviet Union boycotted the Security Council. The second resolution created by the United Nation Command (UNC) was specially designed to assist South Korea. 
Both the Security Council's resolutions had been supported by Ottawa. Lester Pearson, the Canadian Secretary of External Affairs, in response to Canada's support, expressed the hope 'that as a result of the intervention of the United Nations some effective action may be possible to restore peace.'

\section{CANADA AND KOREA}

Canada's involvement in Korea began when it was appointed a member of the Temporary Commission on Korea, which had been established to supervise an election throughout the Korean Peninsular as a prelude to unification and independence. However, the Commission only managed to fulfil their task in South Korea. The Soviet Union did not allow the commission to enter North Korea. Even with this shortcomings, Canada was invited to sit on a second commission, but it refused to join. ${ }^{3}$

In the House of Common, Pearson explained Canada's support for the Security Council's resolutions, with the following: '[a]s hon. Member know, Canada is not now a member of the Security Council and therefore no decision on our part was required ... in regard to this resolution; but I am sure that the House will support, as indeed does the Government, ..." He also reiterated that Canada's support was in accordance with '.. . the action taken by the Security Council, because it represents collective action through the United Nations for peace." This indicated that Canada's support for the Security Council action was taken because it believed that the United Nations was established largely to achieve world peace. Canada believed that a world conflict could be prevented by collective actions in the United Nation. Pearson further hoped that the United Nations action would soon end the Korean War:

Cana I am sure it is the firm hope of all members of this House and of the rity Council and by the Union which has now been taken by the Securesolutions of the Security Cotates Government in conformity with the thereby make possible a council will soon end the war in Korea and long kept that country in resh attempt to compose differences which have to the present outbreak of hostilites The Canadian Prime Minister, L. S. St. Laurent further reiterated
dian involvement in this crisis was to maintain the world peace. 
Any participation by Canada in carrying out the foregoing resolution - and I wish to emphasize this strongly - would not be participation in war against any states. It would be our part in collective police action under the control and authority of the United Nations for the purpose of restoring peace to an area where an aggression has occurred as determined under the charter of the United Nations by the Security Council, which decision has been accepted by us. It is only in such circumstances that this country would be involved in [a] action of this kind. The House, I think, has already approved this position.?

Although Canada had supported the United Nations' resolutions, from the beginning it was undecided how far it would support the UNC. Jean-Francois Pouliot, a Liberal Member of Parliament, questioned the Canadian government's involvement:

What are we going to do about it? What interest do we have in Korea? There may be a few Canadian missionaries of various denominations in that place, but how many are there in South Korea? If Canada is going to support the security council's decision regarding Korea, what form will that support take? It could not be platonic; that is impossible because it is a serious matter...8

With Pouliot's continued questioning, Canada had difficulty to channel its support into action. The difficulty evident before the Korean War broke out. The former Canadian Prime Minister, Mackenzie King tried to isolate Canadian foreign policy after World War II. In 1947, when Canada had been an election observer in Korea, King had told his Cabinet that, ' a great mistake was being made by Canada being brought into [this] situation in Asia . . . of which she knew nothing whatever, of interfering with Great Powers without realizing what consequences might be ?' Unlike King, under Pearson leadership, the External Affairs Department increasingly opened Canada's foreign policy to international affairs.

However, Canada experienced military problems after World War II. In the beginning, Canada had only a limited military capacity to contribute to the UNC. The Canadian Cabinet had voted only to provide its navy and air force to the UNC. In addition, the Minister of National Defence and his officials hesitated about sending a military contingent on the grounds that there were not 
enough adequately - trained troops available. ${ }^{10}$ On July 15,1950 , three Cana. dian destroyers were dispatched. Then, on August 11, 1950, Canada sent a squadron of Royal Canadian Air Forces long-range transport aircraft to South Korea. ${ }^{11}$ These were deemed not enough, and the Secretary General of United Nations, Trygve Lie's telegram castigated Canada for not increasing its participation in the crisis:

In this connection I [Trygve Lie] have been advised that there is an urgent need for additional effective assistance. I should be grateful, therefore, if your government would examine its capacity to provide an increased volume of combat forces, particularly ground forces. ${ }^{12}$

Lie's telegram proved very shameful to Canada, especially to the External Affairs Department.

The External Affairs officials feared that a refusal to contribute ground forces would undermine Canada's credibility in the United Nations. Pearson agreed with their view and brought this matter to Cabinet. ${ }^{13}$ Finally he announced the government's intention to recruit a special force of volunteers for use in carrying out Canada's obligations under the UNC. This brigade force became known as the Canadian Army Special Force. ${ }^{14}$ Canada formed the fourth largest army after the United States, South Korea and United Kingdom. The number of Canadian ground forces totalled 5,403 by the end of June, 1951, and little was changed neither by the end of June 1952 and nor by the end of June 1953. (5,155 and 6,146 respectively) In air power, Canada had provided one squadron which remained unchanged until the end of the war. Canada had despatched three battleships and also remained the same until the end of the war (see appendices B and C .

During the war, Canada advocated two main objectives as achievable. First, to use the United Nations as a channel for a united action in order to free South Korea. Second, this action was to assist the people of Korea to establish peace and order throughout its territory. When this had been done, no nation would exploit the situation for its own advantage. ${ }^{15}$ To achieve these objectives, Canada had outlined four elements of its policy. First, tried to limit the war only to the Korean Peninsular. Second, undertook effort to prevent the allies of North Korea - notably Communist China - from assisting North Korea in this war. Next, Canada did not desire Formosa (Taiwan) became part of this 
conflict. Lastly, endeavoured to end this war as quickly as possible with a cease-ifire ${ }^{16}$ and then began negotiations with North Korea. This brought Canada into line with its second objective: to use its diplomacy and international influence to attain the United Nations' goals on Korea. This also indicated the Canadian hope in wanting to guide the United Nations to avoid an escalation of the war.

\section{CANADIAN CONCERN}

However, her task was not very easy. The Korean War embroiled the big powers the United States, and the then Chinese Communist (potentially the Soviet Union in wanting to protect its interests in the Far East could have been involved as well). Canada wanted to guide the UNC in the same way as it also tried to guide the United States. Canada discovered, however, that was not easy to guide or constrain the United States. In the beginning, Canada was concerned about the United States' unilateral action in Korea, before the Security Council passed its resolutions. The United States' action could potentially divide western unity, especially inside the North Atlantic Treaty Organisation (NATO). Furthermore, Pearson believed that the United States would do little to resist the North Korean Army. Canada wanted the United States to act according to the collective action decided within the United Nations. The Truman declaration, to act within the limits set by the United Nations, had temporary solved Canada's anxiety. ${ }^{17}$

However, during the war, American policy threatened to become a problem and Canada was worried that the Korean War would escalate. When a third resolution on Korea was passed on July 7, 1950, which 'recommended that the Members of the United Nation furnish such assistance to the ROK [South Korea] as may be necessary to repeal the armed attack and to restore international peace and security in the area,' Ottawa was concerned about that 'the area' might well be defined by the United States. ${ }^{18}$ As the first, second and third element of Canada's pclicy toward the Korean War stipulated, Canada wanted the UNC to be concentrated on Korea. A unifying peace in Korea should be the prime task of the UNC. On July 29, 1950, Pearson flew to Washington to inform the United States that the Canadian Army Special Force would be developed under two conditions. First, the troops were only to be trained to the satisfaction of their Canadian officers and second, the force would not be involved in the defence of Formosa. ${ }^{19}$ 
This matter became increasingly crucial when MacArthur landed successfully in Inchon on September 29, 1950. By this action, the UNC was able to drive the North Koreans back to the $38^{\text {th }}$ parallel. The success of this landing made Canada both fearful and worried. Should the phrase 'in area' only be confined to South Korea. MacArthur had asked Truman for permission to allow the UNC to cross the $38^{\text {th }}$ parallel. Pearson, in his statement, had expressed his concerns about the new developments in the Korean War. 'The decision to authorise the United Nations forces to cross that line (the $38^{\text {th }}$ parallel) could not be taken lightly, and it was not taken lightly. ${ }^{20}$ However, in Washington, Truman had given MacArthur the green light to lead the UNC into North Korea. ${ }^{21}$

Meantime, in Peking, K. M. Panikkar, the Indian ambassador to Peking, had send warning from Peking that China would intervene in the conflict if the UNC crossed the $38^{\text {th }}$ parallel. President Truman took this warning lightly, and did not withdraw his order to cross the $38^{\text {th }}$ parallel. Chou En-lai, the Chinese Prime Minister, reiterated his warning that China would intervene. Chou told Panikkar on October 3, 1950 that while the 'South Koreans [already in North Korea territory] did not matter. American intrusion into North Korea would encounter Chinese resistance. ${ }^{22}$ China was concerned that America would force the war onto its territory.

On September 28, 1950, Escott Reid (an officer in the Canadian External Affairs Department) informed Pearson that ' . . . the dangers implicit in the assumption that the objectives of the United Nations military action in Korea should now be changed from repelling aggression to achieving the unification of Korea. ${ }^{23}$ He urged the United States to stop their advance and begin negotiations on the cessation of the conflict. In the United Nations' General Assembly, the United States had proposed to introduce a resolution to cross the $38^{\text {th }}$ paral. lel. Pearson tried to prevent this resolution from being tabled, but failed to do so. Furthermore, the United States succeeded in getting Britain and seven other countries sponsor the resolution. To the United States, this resolution was aimed at 'all appropriate steps be taken to ensure conditions of stability through Korea.' 'I Ironically, in the end, Canada had to support the United States' resolution. Canada could not restrain the United States' resolution without the support of other western counties because it did not want to drive the western countries' unity. Canada had hoped that the UNC advance would not be allowed to proceed beyond the narrow waist of the Korean peninsula (roughly half-way between the $38^{\star}$ parallel and the Manchurian border). ${ }^{35}$ On October 7, 1950, 
the United Nations' General Assembly adopted the American resolution which was carried out by a vote of $47-5$, with seven abstentions.

Back in Peking, China's warning was not merely an empty threat. By the end of November 1950, 300,000 Chinese troops ${ }^{26}$ had driven the UNC into a chaotic 120-mile retreat down the peninsular back to the $38^{\text {th }}$ parallel. Indoing so, it inflicted heavy causalities on the UNC forces. Canada knew this would happen if the UNC continued to advance into North Korea. With this development, Canada began to realise that the objective, to achieve a peaceful and unified Korea by force of arms, was incompatible with Peking's view of the requirements of Chinese security. ${ }^{27}$ Canada again tried to use the conciliatory diplomacy in this war, in order to seek peace. Canada had urged the United Nations to propose a cease-fire. If that concession was gained, it would begin negotiations, and later peace would be forthcoming. These were the measures that Canada hoped would bring lasting peace and unity in Korea and settle the Far East's problem for good. Pearson explained the project thus:

The supplementary report of the United Nations group on [the] cease-
fire in Korea, which was made public on January 11, 1951, clearly pro-
posed that the Far Eastern situation should be dealt with in three stages.
The first, cease-fire in Korea; the second, the settlement of the Korean
question, and the third, the settlement of other Far Eastern questions. All
western dealings with the enemy in Korea have been based on this three-
stage program, and we cannot now reasonably expect to ask our allies,
particularly the United States, to abandon this procedure. Therefore 1
suggest we must continue to try to get the armistice first and then political
talks afterwards.2s

With this formula, Canada was able to use conciliatory diplomacy to settle the problem. Canada also implored the United Nation to adapt this formula.

Before the speech was made in the United Nation, Pearson had been appointed as one of the three members of a Cease-Fire Group. The other member included Nasrollah Entezan of Iran and Sir Benegal Rau of India." This group was designed to engage in talks with China and to persuade China to accept a cease-fire in Korea. However, this group's tasks had been interrupted by two events in which the American was involved. In Pearson's memoirs, be stated that; " . . in our first series of meetings from 15 to 19 December 1950, We (the cease-fire group) failed not only to find any solution but akso even to 
meet with the delegation of Communist Chinese, under the leaderships of Gen. eral Wu Hsui-Chuan, . . . ${ }^{30}$

The first event, that handicapped the Cease-Fire Group was MacArthur's order, on November 5, 1950, to the American Air Force to bombard the twin spans from Sinuiju, Korea to Antung, Manchuria, in an effort to cut the flow of supplies and personnel flowing across the border from China. ${ }^{31}$ Truman had given permission to MacArthur to proceed with the UNC task. It carried out its job on November 8, 1950. This move aroused anxiety in the Canadian Department of External Affairs. The American policy had deviated from the United Nation's original objectives. Ottawa called on Washington to avoid approaching the Yalu River. An advance as far as the Yalu River would provoke China and possibly the Soviet Union which also had a border near the river. Canada sug. gested that a buffer state in the northern area of Korea be established. Pearson said that; ' . . . in private discussions at the United Nations, the proposal that a buffer state should be left along the northern boundary of Korea in order to avoid giving any excuse for suspicion on the part of the Chinese government that its legitimate interests might be in danger. . . ${ }^{32}$ This proposal was made to prevent any possible escalation of the war with China; ' $\ldots$ we were and are determined, along with other delegations, to do everything we can to prevent a war with China, whether limited or unlimited." 33

Despite this, Canada in favour with MacArthur conducted the UNC. MacArthur brought many problem in this war and was also largely responsible for the heavy casualties suffered by the UNC. On the other hand, he also steered the UNC well away from its original objective. 'As long as he [MacArthur] was in charge of the United Nations forces it would be difficult to bring the war to an end. ${ }^{34}$ His objective was no other than victory. Pearson said that '... the object of war is peace; ... ${ }^{35}$ Mac Arthur was not concerned on what measures should be taken in order to win the war. Furthermore, his aim was not only to win the Korean War but to bombard Manchuria and advance further north into Peking. Speaking to the Canadian Bar Association in Toronto, on March 3, 1951, Pearson commented on MacArthur's behaviour.

... when those who have been charged by the United Nations with military responsibility make controversial pronouncements which go far beyond that responsibility, and create confusion, disquiet and even discord. It seems to me to be as unwise, indeed as dangerous, for the 
generals to intervene in international policy matters as it would be for the diplomats try and lay down military strategy. This is a case, I think, where the specialist should stick to his specialty. Otherwise, wholehearted cooperation between friends which is so essential is hindered. ${ }^{36}$

Worries about MacArthur was finally put to rest when Truman recalled him on April 11, 1951, and replaced him with General Ridgway.

However, the problem did not end there, for Canada was still advocating the need to avoid an escalation war in the Far East. With its Eurocentric view, Canada had increasing fear that the United States' concentration in Korea could weaken the defence in Western Europe. Pearson expressed his feelings about the situation in Korea in his memorandum to his cabinet, December, 28, 1950, when he stated that ' $[t]$ he present military weakness of Western Europe is one of the basic reasons why we have contended that all possible steps should be taken to avoid becoming embroiled in a war with Communist China. ${ }^{37}$

\section{PROBLEM WITH AMERICANS}

On November 30, 1950, Truman had expressed his regret that the Chinese Communist had intervened in the war. He pledged that his government would use any measure including 'every weapon that we have'. ${ }^{38}$ In order to win the war, Truman's statement gave vent to anxiety and fear that the United States would use another atomic bomb in Asia. Pearson had given his opinion that the use of an atomic bomb would not have a positive impact: ' $[t]$ he military may argue that the atomic bomb is just another weapon. But, in the minds of ordinary people everywhere in the world, it is far more than that and has acquired an immensely greater intrinsic significance. ${ }^{39}$ An atomic bomb attack against China's cities might change Asia's attitude towards Western countries for ever.

The strategic use of the bomb against Chinese cities might conceivably change the course of military events in Asia now, but at the risk of destroying the cohesion and unity of purpose of the Atlantic Community. Certainly its use, for a second time, against an Asian people would dangerously weaken the links that remain between the Western World and the people of the East. ${ }^{40}$

The second event hampered the Cease-Fire Group occurred, when the United States introduced a new United Nations resolution that named China as the aggressor. With this stage, the United States had virtually 
guaranteed that the Korean War would be increasingly more difficult to end. Pearson did not agree with this tactic and said that, to name China as the aggressor. Canada tended to regard the Chinese intervention as what Peking called it prerogative to protect its vital national interest. On the other hand, the United States interpreted the Chinese counter-offensive as a 'Cold War' in the East." Canada urged the United Nations to limit its objective in the Korean theatre, and to convince the Peking regime that the security of Chinese territory was not under threat. ${ }^{42}$ Pearson warned the United Nations that 'military operations against the territory of China itself ... might well result in Soviet assistance to the Chinese forces. ${ }^{1 / 3}$

Canada thought that there was still hope for a settlement and an end to the war through the avenue of the diplomacy. India seemed to be the only intermediary Canada could use to approach China. Canada used India to try to find out whether China would be willing to withdraw from North Korea. Through the India embassy in Peking, China had intimated that she had considered calling her troops out from Korea and to call for a cease fire. This was on condition that it wanted Korea's problems to be resolved by the Korean people. China also demanded the United States armed forces should be withdrawn from Taiwan and the Taiwan Straits in accordance with both the Cairo Declaration and the Postdam Declaration. Lastly, China asked that a legitimate status for the People's Republic of China in the United Nations be ensured before she withdrew her troops. ${ }^{41}$ Thus, there seemed to be positive signs coming out of China to find a way to resolve the conflict. India quickly introduced, in the United Nations General Assembly, a 48-hour adjournment of the Korean proceedings in order to permit further study. 45

When India's resolution was adopted, the United States accused Canada of negotiating with Peking behind its back. ${ }^{16}$ The United States Secretary of State for External Affairs, Dean Acheson was not optimistic about negotiations with China. Furthermore, China's demands, as mention above, were acceptable by the United States." Canada still clung onto its three stage formula to end the Korean War. The United States thought that China should be put in pressure under order to end the war. By condemning China as the aggressor in the conflict it was hoped that China would be forced to withdraw from Korea and begin talk. The United States' aimed at negotiating a settlement to the dispute United Nations resolution had been supported by the larger Western countries. The demand for unity among the Western countries and the need to avoid aliet 
ating the United States from the United Nation machinery of the resolution, forced Canada to decide to vote the United States' resolution and it abstained from India's one. Pearson had explained the Canada's position in his letter to India's Prime Minister, Nehru:

For us, they arose equally out of our attitude towards the collective security system and our relationships with our great neighbours. It has always been clear to us that once we were faced with the question of whether or not the Chinese had participated in an aggression in Korea, we could not otherwise than answer yes. ${ }^{48}$

Through this statement, Canada seemed to be under American pressure to support its resolution. This view was reinforced with the adoption of the United Nations embargo on the shipment of arms and strategic material to China: Canada followed suit and embraced this action. ${ }^{49}$ The United States' resolution had forced China's hand, and she rejected any political negotiations with the United Nation, ${ }^{50}$ unless they dropped the resolution labelling them the aggressors in the conflict.

At this stage, any hope for a cease fire was banished, and it was left for a time to decide on an agreement to achieve a cease fire. The moment for negotiations finally arrived on July 10,1951. However, it took two years to end the war. On July 27, 1953, the cease fire was signed and war was ended.51 Although the fighting had stopped, the negotiations continued at the Geneva Conference well into 1954. Despite the talks, little progress was made, and the peninsula is still divided by the $38^{\text {th }}$ parallel today.

\section{CONCLUSION}

In conclusion, we can say that Canada's participation in this war could be divided by two functions. Firstly, Canada provided military support for the UNC. At the beginning of this conflict, Canada was reluctant to commit its ground forces. It only agreed, originally, to send a destroyer and its aircraft to the UNC. On the question of ground forces, it had problems organising them since the end of World War II. To maintain its reputation in the United Nations, Canada agreed to send her ground forces to support the UNC. Canada's ground force Was the fourth largest in the UNC. At the end of the war, Canada's army had suffered heavy casualty 294, 1,202 wounded, and about 47 missing. (see 
Appendix C). According to Robert Botwell, Canada actually lost 312 died with 1557 casualties. . $^{22}$

Secondly, Canada had done its best to use its influence and diplomatic role to end the war by its three stage diplomacy, that is, cease-fire, armistice and negotiation. This solution was not only aimed at Korea, but also be applicable to the Far East's further problems. On the other hand, Canada had tried to constrain the Americans in Korea. With their four elements, Canada had hoped it could direct the United Nations (and America) to be able to achieve peace and unity in Korea. However, it realised it was not an easy task to order the United States to follow its policy. The United States was hard to control. To America, the Korean War did not mean a Korean internal problem, it had the wider implication of being a war against communism. It could use every weapon it felt likely to stop what it saw as growing communist influence in the world, and it wanted the communists to follow its conditions in negotiation for a peace. In naming the China as the aggressor the United States was trying to pressure China into talks. Canada had taken the conciliatory approach, and urged the United Nations to assure China that the United Nations did not want to disrupt its interests. Canada believed this China would agree with the United Nations' guarantee.

Then, Canada began indirect talks with China through the intermediary of India. It also joined the cease-fire group and initially was an enthusiastic supporter of India's resolution in it efforts to seek a peaceful solution. On India's resolution, she believed that the way, was open to cease-fire and settlement. But, America applied pressure and forced Canada to abandon its conciliatory policy. When we examine the four elements of Canada's policy, only the third, was aimed at preventing the involvement of Taiwan. The first only enjoyed limited success, when it tried to avoid the war reaching beyond the Korean Peninsula, and prevent the Americans going far beyond Korea's boundary. The second failed when China intervened in the war. The last element had taken a long time to come to fruition: the cease-fire finally ended the war, but did not settle the Korean problem to any degree of satisfaction.

Canada did not want to isolate America from using the United Nations' machinery, and policy making nor did it want to divide Western unity. These two reasons had turned its policy around toward the American position. This signalled that Canada's efforts to constrain the United States had failed. In other words it was the United States who forced Canada to support the United States 
action. Canada was only the middle power among the Western countries, and could not in isolation, oppose totally the American policy. But, she could use persuasion on the Americans. After all, Canada had much in common with the United States: the same ideology, was bound by a common border, had economic connection, was of both the NATO and the United Nations. In short, Canada could not run from the Americans. Pearson put it succinctly when he said that, '[I]f Washington 'wend it alone', where would Ottawa go?'s3 


\section{NOTE}

1 Martin Kitchen, "From the Korean War to Suez: Anglo-American-Canadian Re. lations, 1950-1956," edited by B. J. C. McKercher and Lawrence Aronsen, The North Atlantic Triangle in a Changing World: Anglo-American-Canadian Rela. tions, 1902-1956, (University of Toronto Press, Toronto, 1996), p.220. The India government announced a few days later that it supported the resolution. The Egyptian ambassador said that his government would have asked him to abstain.

2 Dennis Stairs, "Containing Communism in Korea, 1950-53,' Don Munton and John Kirton, Canadian Foreign Policy: Selected Cases, (Prentice-Hall Canada, inc., Scarborough, Ontario, 1992), p.49.

3 R. A. Mackay, Canadian Foreign Policy: Selected Speeches and Documents. (McClelland and Stewart Limited, Toronto, Montreal, 1971), p.294.

4 Ibid., p.296.

5 Ibid.

6 Ibid., p.294.

7 Ibid, p.298.

8 Ibid., p.297.

9 J. W. Pickersgill and D. F. Foster, The Mackenzie King Record. IV 1947-1948. (University of Toronto Press, Toronto, 1970), p.134.

10 John Hilliker and Donald Barry, Canada's Department of External Affairs, Vot ume 2 Coming of Age, 1946-1968. (McGill-Queen's University Press, Montreal \& Kingston, 1995), p.79.

11 Dennis Stairs, "Containing Communism In Korea, 1950-53," p..51.

12 MacKay, op. cit., p. 300.

13 John Hilliker and Donald Barry, ep. cit., p.79.

14 MacKay, op. cit., p.304.

15 H. F. Angus, Canada and the Far East 1940-1953, (University of Toronto Press, 1953), p.49.

16 Dennis Stairs, "Containing Communism In Korea, 1950-53," p .93.

17 Robert Botwell, Pearson: His Life and World, (McGraw-Hill Ryerson Limited, Toronto, 1978), pp.70 - 71

18 Martin Kitchen, QD. cit., p.223.

19 Dennis Stairs, “Containing Communism In Korea, 1950-53," p. 52.

21 Dennis Stairs, "Containing Communism In Korea, 1950-53," p..53.

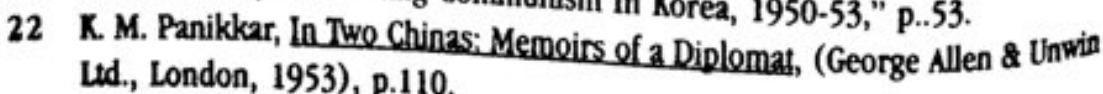


23 J. L. Granatstein, A Man of Influence: Norman A. Robertson and Canadian Statecraft 1929-68, (Deneau Publishers \& Company Ltd., 1981), p.270.

24 Dennis Stairs, "Containing Communism In Korea, 1950-53," p.53.

25 Ibid., pp.53 - 54.

26 Peter Lane, The Postwar World: An Introduction, (B. T. Batsford Ltd., London, 1987), p.265.

27 Denis Stairs, The Diplomacy of Constraint: Canada, the Korean War, and the United States, (University of Toronto Press, Toronto and Buffalo, 1974), p.128.

28 Mackay, op. cit., p.313.

29 Dennis Stairs, "Containing Communism In Korea, 1950-53," p.55.

30 Lester B. Pearson, The International Years, Volumes II, 1948-1957, (University of Toronto Press, Toronto, 1973), p.187.

31 Denis Stairs, The Diplomacy of Constraint: Canada, the Korean War, and the United States, p.129.

32 MacKay, op. cit., p.307.

33 Ibid.

34 Pearson, op. cit., p.179.

35 Ibid.

36 Ibid., p.180.

37 James Earys, In Defence of Canada: Growing Up Allied , (University of Toronto Press, Toronto, 1980), p.374.

38 Denis Stairs, The Diplomacy of Constraint: Canada, the Korean War, and the United States, p.146, in Truman Years of trial and hope, pp.442-4.

39 James Earys, op. cit., p.374.

40 Ibid., pp.375-376.

41 Denis Stairs, The Diplomacy of Constraint: Canada, the Korean War, and the United States, p.148.

42 Dennis Stairs, "Containing Communism In Korea, 1950-53," p.55.

43 Denis Stairs, The Diplomacy of Constraint: Canada, the Korean War, and the United States, p.149, Department of External Affairs, Statements and Speeches, no. $50 / 50$.

44 Pearson, op. cit., p.189.

45 Dennis Stairs, "Containing Communism In Korea, 1950-53," p.56.

46 Ibid., p.56.

47 Denis Stairs, The Diplomacy of Constraint: Canada, the Korean War. and the United States, p.153.

48 Documents on Canadian External Relations 1951. Vol.17, (Canada Communication Group, Ottawa, 1996), pp.99-100. 
49 Angus, op. cit., p.51.

50 Pannikar, op. cit., p.124.

51 Robert Botwell, op. cit., p.71.

52 Ibid.

53 John Hilliker and Donald Barry, op. cit., p.80, look at Dennis Stairs, "Canada and the Korean War: The Boundaries of Diplomacy," International Perspectives (Nov-Dec., 1972) : 32 ; Lester B. Pearson, "The Development of Canadian Foreign Policy," Foreign Affairs 30, no.1 (October 1951) : 26. 


\section{APPENDIX A}

Military Contributions to the United Nations Command. (Ground Forces)

\begin{tabular}{lrrr}
\hline Countries / Date & Jun 30,1951 & Jun 30,1952 & July 31,53 \\
\hline United States & 253,250 & 265,864 & 302,483 \\
Republic of Korea & 273,266 & 376,418 & 590,911 \\
(South Korea) & & & \\
United Kingdom & 8,278 & 13,043 & 14,198 \\
Canada & 5,403 & 5,155 & 6,146 \\
Turkey & 4,602 & 4,878 & 5,455 \\
Ethiopia & 1,153 & 1,094 & 1,271 \\
Philippines & 1,143 & 1,494 & 1,496 \\
Columbia & 1,050 & 1,007 & 1,068 \\
Thailand & 1,057 & 2,274 & 1,294 \\
Greece & 1,027 & 899 & 1,263 \\
Australia & 912 & 1,844 & 2,282 \\
New Zealand & 797 & 1,111 & 1,389 \\
France & 738 & 1,185 & 1,119 \\
Netherlands & 725 & 565 & 819 \\
Sweden & 162 & 148 & 154 \\
Belgium & 602 & 623 & 944 \\
Norway & 79 & 109 & 105 \\
Italy & 0 & 64 & 72 \\
India & 333 & 276 & 70 \\
\hline Total & 554,577 & 678,051 & 932,539 \\
\hline
\end{tabular}

Source: James I Matray, Historical Dictionary of The Korean War, Greenwood Press, New York, 1991, p.552. 


\section{APPENDIX B}

Military Contributions to the United Nations Command. Air Forces (Squacirons)

\begin{tabular}{lrrr}
\hline Countiries / Date & Jun 30, 1951 & Jun 30, 1952 & July 30, 1953 \\
\hline United States & 58 & 67 & 66 \\
Australia & 1 & 1 & 1 \\
Canada & 1 & 1 & 1 \\
South Airica & 1 & 1 & 1 \\
\hline Total & 61 & 70 & 69 \\
\hline
\end{tabular}

Source: James 1 Matray, Historical Dictionary of The Korean War, Greenwood Press, New York, 1991, p.552.

\section{APPENDIX C}

Military Contributions to the United Nations Command. Naval forces (Ships)

\begin{tabular}{lccc}
\hline Countries / Date & Jun 30, 1951 & Jun 30, 1952 & July 30, 1953 \\
\hline United States & 186 & 195 & 261 \\
$\begin{array}{l}\text { Republic of Korea } \\
\text { (South Korea) }\end{array}$ & 34 & 67 & 76 \\
\hline Countries / Date & January 15, 1952 & October 15, 1952 \\
\hline United Kingdom & 22 & 22 \\
Australia & 4 & 4 \\
Canada & 3 & 3 \\
Colombia & 1 & 1 \\
Denmark & 1 & 1 \\
Netherlands & 1 & 1 \\
Thailand & 2 & 2 \\
New Zealand & 2 & 2 \\
\hline
\end{tabular}

Source: James I Matray, Historical Dictionary of The Korean War, Greenwood

Press, New York, 1991, p.552. 


\section{BIBLIOGRAPHY}

\section{Documentary sources}

pocuments on Canadian kxternal Relacions i 451 , Vot.17, Cariada Conmunication Group, Otawa, 1496

Mackay, R. A, Canadian Foreign Yolicy: Selecred speecnes anc bocuments, McClelland and stewart Limuted, Torono, Monureal, 1971.

\section{Memoirs}

Panikkar, K M., In Two Chinas: Mennoirs of a Diplowal, (George Allen \& Unwin Ltd., London, 1953.

Lester B. Pearson, The International Years, Voluries II, 1948-1457, Uniwersity of Toronto Press, Torunio, 1973.

\section{Biographies}

Botwell, Kobert, Pearson. His Life and World, McGraw-Hill kyerson Limuted, Toronto, 1978.

Granatstein, J. L., A Man of Influence: Norinan $\mathrm{A}$, koverison and Ganadian Statecrafi 1929-68. Deneau fublishers \& Company Ltd., 1981.

Pickersgill, J. W, and D. F. Foster, the Mackenzie King Kecori, JV 1947-1948, Unswersiy of Toronto Press, Toronto, 1970.

\section{Secondary Works}

Angus, H. E, Canada and the Far kast 1440-1453 University of Toronto Yress, 1953.

barys, James, In Defelice of Canala Gruwing Uf Allied, University of foronto Press, Toronto, 1980.

Hilliker, John and Lonaid Barry, Sanada's Depariment of Exlemal Afíairs. Yolume 2 Coming of aqe, 1946-1968, McGill-Queen's University Press, Montreal \& Kingston, 1995.

Lane, Peter, The Pustuar World: An Intraducion, B. T. Bassford Led., London, 1987.

Stais, Denis, The Diplomacy of Constraint Canada, the Kortean War, and the United Siates, University of Toronto Press, Toronio and Buffalo, 1974. 


\section{Article}

Dennis Stairs, "Containing Communism in Korea, 1950-53,' Don Munton and John Kirton, Canadian Foreign Policy: Selected Cases (Prentice-Hall Canada, inc., Scarborough, Ontario, 1992.

Martin Kitchen, "From the Korean War to Suez: Anglo-American-Canadian Rela. tons, 1950-1956," edited by B. J. C. McKercher and Lawrence Aronsen, The North Alantic Triangle in a Changing World: Anglo-American-Caradian Relations, 1902-1956, University of Toronto Press, Toronto, 1996.

\section{Dictionary}

Matray, James I, Historical Dictionary of The Korean War, Greenwood Press, New York, 1991. 